\title{
Intramedullary Ganglioglioma of Spinal Cord
}

\section{-Case Report-}

\author{
Kazufumi KAMIKASEDA, Tosuke TAKAKI* and Takashi HIKITA* \\ Department of Neurosurgery, Kaizuka Hospital, Fukuoka; \\ *Department of Neurosurgery, Hamanomachi General Hospital, Fukuoka
}

\begin{abstract}
Gangliogliomas occur least commonly in the spinal cord. A case of ganglioglioma of C8-Th1 spinal cord in a 24-year-old male is reported. Magnetic resonance imagings are an important element of diagnosis and treatment.
\end{abstract}

Key words: ganglioglioma, spinal cord tumor, magnetic resonance imaging, malignant transformation

\section{Introduction}

Gangliogliomas (synonyms include gangliocytoma, ganglioneuroma, ganglioglioneuroma, and neuroastrocytoma) are rare, usually slowly growing, well circumscribed lesions, and are often characterized as essentially hamartomatous. They constitute only $1.1 \%$ of all spinal cord tumors ${ }^{20)}$ and only 14 cases of intramedullary gangliogliomas have been reported in the literature.

We present the case of a young adult male who underwent successful removal of an intramedullary cervicothoracic spinal cord tumor with the histological appearance of a ganglioglioma.

\section{Case Report}

The patient was a 24-year-old male who had developed twitching of the left hand at the age of 8 years. His left hand was smaller than the right, and weaker in grasping power. He also developed left ptosis while in elementary school. Although he was an excellent athlete and participated in high school and university sports, he sprained his left ankle several times. In 1987, left gait disturbance appeared, and he was hospitalized on March 15, 1988.

His left extremities were smaller than the right extremities and the left hand muscles were atrophic. $\mathrm{He}$ had a nuchal port wine nevus and thoracic

Received March 6, 1989; Accepted July 27, 1989 dextro-convex scoliosis. Neurological examination on admission disclosed muscle weakness of the left upper and lower extremities, particularly of the distal muscles of the upper extremity. He also exhibited left hyperreflexia, spasticity of the left lower extremity with ankle clonus and Babinski's sign, dissociated sensory loss at the C6-8 levels, and Horner's signs (partial ptosis and pupillary miosis without anhidrosis of the face) on the left side. Spinal $\mathrm{x}$-rays demonstrated no definite abnormality. Computed tomography (CT) showed cervical cord enlargement without contrast enhancement at the C6-7 vertebral levels. Magnetic resonance (MR) imaging disclosed an intramedullary lesion that displaced the spinal cord at the C6-7 vertebral levels. The lesion appeared as an area of isointensity surrounded by high intensity on $T_{1}$-weighted image, and as a high-intensity region on $\mathrm{T}_{2}$-weighted image. The posterior border of the $\mathrm{C} 6$ and $\mathrm{C} 7$ vertebral bodies showed a mild anterior-convex curvature (Fig, 1).

He underwent C5-7 laminectomies. The dura mater and arachnoid appeared normal. The spinal cord was swollen from the $\mathrm{C} 8$ to the Thl segment. Abnormal vessels, including red veins, were observed on the dorsal surface of the spinal cord immediately above the tumor. Incision of the left posterior column exposed an intramedullary tumor. The tumor was firm and pinkish-gray, and there was a distinct cleavage plane between the tumor and the adjacent spinal cord. It was totally removed. 

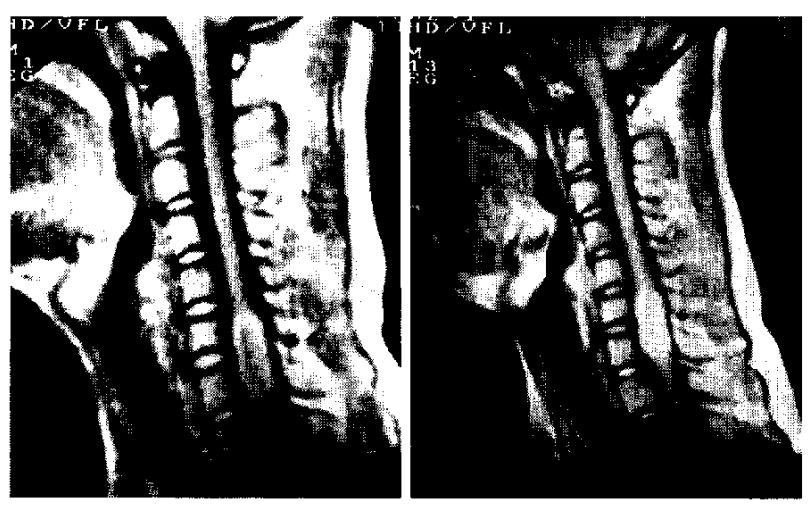

Fig. $1 \mathrm{~T}_{1}$ - (left) and $\mathrm{T}_{2}$-weighted (right) sagittal MR images, showing an intramedullary spinal cord mass.

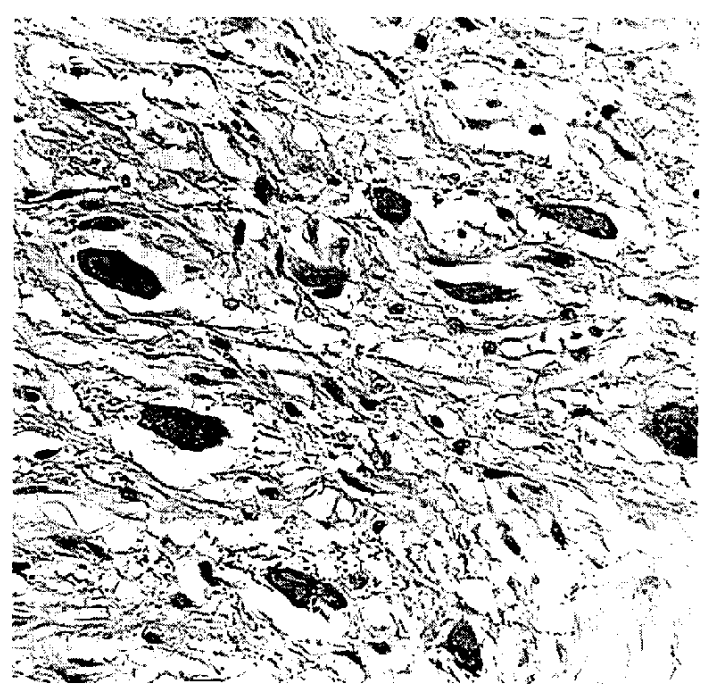

Fig. 2 Photomicrograph of a tumor specimen. The tumor is composed predominantly of mature ganglion cells, associated with glial elements. HE stain, $\times 275$.

Histological study showed the tumor to consist predominantly of mature ganglion cells, with associated glial elements. In some parts of the tumor, the glial cell density was high, glial fibers were clearly identified by Bodian staining, and there were numerous calcifications. The histopathological diagnosis was ganglioglioma (Fig. 2).

Postoperatively, he did well. Although the sensory disturbance gradually localized to the ulnar distribution of the left hand, the weakness of the left hand muscles somewhat worsened. His gait was abnormal, but he was able to walk unassisted. Postoperative MR images showed disappearance of the tumor and narrowing of the spinal cord where the tumor had been. Radiation therapy was not administered.

\section{Discussion}

Pick and Bielshowsky ${ }^{15}$ first introduced the term "Ganglioglioneurom" in 1911. The term "ganglioglioma" was proposed by Perkins ${ }^{14)}$ in 1926 and adopted by Courville ${ }^{3)}$ in 1930. Gangliogliomas are relatively benign, slowly growing tumors composed of mature ganglionic cells and nonganglionic glial elements. Lesions with non-neoplastic stroma, especially those composed of astrocytic cells, are termed "ganglioneuroma" or "gangliocytoma," whereas tumors comprising neoplastic astrocytes are designated "'ganglioglioma." However, it is difficult to differentiate gangliocytoma from ganglioglioma because neoplastic evolution of the glial components varies from case to case, and even in different areas of the same lesion. ${ }^{4,16,17)}$

For this reason, unequivocal gangliogliomas of the central nervous system are rare; the incidence is reportedly $0.4-1.7 \%$ of all central nervous system tumors. ${ }^{4,7)}$ Gangliogliomas are most often located in the cerebral hemispheres, particularly the temporal lobes and third ventricle, and are also found in the brainstem and cerebellum. , $^{3,4,6,17,20)}$

Gangliogliomas of the spinal cord are extremely rare. ${ }^{12,20)}$ Zimmerman $^{201}$ reported an incidence of $1.1 \%$ of all spinal cord tumors, and we found only 15 reported cases (Table 1). ${ }^{1,2,5,7-11,13,15,19)}$ The first successful removal of such a tumor was achieved by Kernohan et al. ${ }^{9)}$ in 1932. The average age of the patients reported to date was 23 years, the range being $2.5-78$ years, and $80 \%$ were under 30 years of age. The sex ratio was $3: 2$, males to females. The portion of the cord most affected was the cervical segment, accounting for $67 \%$ of cases. The average duration of symptoms in the adult patients was 7.8 years, and the range was 3-16 years.

Gangliogliomas are generally benign and grow slowly. Malignant transformation is extremely rare and can occur, at least theoretically, along both the ganglionic and glial cell lines. ${ }^{11)}$ Bevilacqua and Sarnelli ${ }^{2)}$ reported a case of malignant ganglioglioma of the spinal cord in which both the ganglionic and glial cells were anaplastic, sometimes markedly so. However, when this type of tumor undergoes malignant change, it usually occurs in the glial rather than the ganglionic element. ${ }^{16)}$ Kalyanaraman and Henderson $^{8)}$ emphasized the importance of distinguishing ganglioneuroma from ganglioglioma; they are histologically similar but, ganglioglioma has a greater potential for malignant transformation. In our case 
Table 1 Summary of reported cases of ganglioglioma of the spinal cord

\begin{tabular}{|c|c|c|c|c|c|c|c|}
\hline Author (Year) & $\begin{array}{l}\text { Age, } \\
\text { Sex }\end{array}$ & Diagnosis & Site & $\begin{array}{l}\text { Duration of } \\
\text { symptoms* }\end{array}$ & Surgery & $\begin{array}{l}\text { Duration of } \\
\text { follow-up }\end{array}$ & Outcome** \\
\hline $\begin{array}{l}\text { Pick \& Bielshowsky } \\
(1911)^{15)}\end{array}$ & $24, F$ & ganglioglioneuroma & medulla-C2 & $\begin{array}{l}\text { not } \\
\text { reported }\end{array}$ & $\begin{array}{l}\text { not } \\
\text { performed }\end{array}$ & $\begin{array}{l}\text { not } \\
\text { reported }\end{array}$ & died \\
\hline Foerster $(1924)^{5}$ & $24, M$ & ganglioneuroma & $C 4-6$ & $\begin{array}{l}\text { not } \\
\text { reported }\end{array}$ & $\begin{array}{l}\text { not } \\
\text { performed }\end{array}$ & $\begin{array}{l}\text { not } \\
\text { reported }\end{array}$ & died \\
\hline Karnohan et al. $(1932)^{91}$ & $34, \mathrm{~F}$ & gangliocytoma & $\begin{array}{l}\text { cervico- } \\
\text { thoracic }\end{array}$ & $3 \mathrm{yrs}$ & $\begin{array}{l}\text { subtotal } \\
\text { removal }\end{array}$ & $7 \mathrm{mos}$ & died \\
\hline$"$ & $27, \mathrm{~F}$ & gangliocytoma & C $1-8$ & $4.5 \mathrm{yrs}$ & $\begin{array}{l}\text { subtotal } \\
\text { removal }\end{array}$ & $12 \mathrm{yrs}$ & mild deficit \\
\hline $\begin{array}{l}\text { Lichtenstein \& Zeitlin } \\
(1937)^{13)}\end{array}$ & $20, \mathrm{M}$ & ganglioglioneuroma & thoracic & $\begin{array}{l}\text { not } \\
\text { reported }\end{array}$ & $\begin{array}{l}\text { not } \\
\text { performed }\end{array}$ & $\begin{array}{l}\text { not } \\
\quad \text { reported }\end{array}$ & $\begin{array}{l}\text { not } \\
\text { reported }\end{array}$ \\
\hline Garrido et al. $(1978)^{7)}$ & $12, \mathrm{M}$ & ganglioglioma & $\begin{array}{l}\text { medulla- } \\
\text { cervical }\end{array}$ & $1 \mathrm{yr}$ & biopsy only & $8 \mathrm{mos}$ & mild deficit \\
\hline " & $4, F$ & ganglioglioma & $\begin{array}{l}\text { cervico- } \\
\text { thoracic }\end{array}$ & 4 mos & $\begin{array}{l}\text { total } \\
\quad \text { removal }\end{array}$ & 2 yrs & mild deficit \\
\hline " & $10, \mathrm{M}$ & ganglioglioma & $\begin{array}{l}\text { cervico- } \\
\text { thoracic }\end{array}$ & $1 \mathrm{mo}$ & $\begin{array}{l}\text { partial } \\
\text { removal }\end{array}$ & $5 \mathrm{yrs}$ & asymptomatic \\
\hline " & $2.5, \mathrm{~F}$ & ganglioglioma & $\begin{array}{l}\text { cervico- } \\
\text { thoracic }\end{array}$ & 3 yrs & biopsy only & $3 \mathrm{yrs}$ & severe deficit \\
\hline $\begin{array}{c}\text { Bevilacqua \& Sarnelli } \\
(1979)^{21}\end{array}$ & $78, \mathrm{M}$ & ganglioglioma & Th3-6 & 4 yrs & laminectomy & 5 yrs & died \\
\hline Albright \& Byrd $(1980)^{\prime \prime}$ & $11, \mathrm{M}$ & ganglioglioma & $\begin{array}{l}\text { medulla- } \\
\text { conus }\end{array}$ & $1 \mathrm{yr}$ & $\begin{array}{l}\text { total } \\
\text { removal }\end{array}$ & $4 \operatorname{mos}$ & mild deficit \\
\hline $\begin{array}{l}\text { Kalyanaraman \& } \\
\text { Henderson }(1982)^{81}\end{array}$ & $58, \mathrm{M}$ & ganglioneuroma & C5-7 & 14 yrs & $\begin{array}{l}\text { total } \\
\quad \text { removal }\end{array}$ & $\begin{array}{l}\text { not } \\
\text { reported }\end{array}$ & unknown \\
\hline Wald et al. $(1985)^{19\}}$ & $2.5, \mathrm{M}$ & ganglioglioma & conus & $1.5 \mathrm{yrs}$ & $\begin{array}{l}\text { total } \\
\text { removal }\end{array}$ & $15 \mathrm{mos}$ & asymptomatic \\
\hline Kitano et al. $(1987)^{11)}$ & $19, \mathrm{~F}$ & $\begin{array}{l}\text { malignant } \\
\text { ganglioglioma }\end{array}$ & Th1-8 & $5.5 \mathrm{yrs}$ & biopsy only & $18 \mathrm{mos}$ & died \\
\hline Present case & $24, \mathrm{M}$ & ganglioglioma & C8-Th1 & $16 \mathrm{yrs}$ & $\begin{array}{l}\text { total } \\
\text { removal }\end{array}$ & $1 \mathrm{yr}$ & mild deficit \\
\hline
\end{tabular}

*Interval between the onset of symptoms and the first operation. ${ }^{* *}$ Severe deficit: bedridden, incapacitated; mild deficit: focal neurological deficit but ambulatory and self-sufficient.

the glial component of the tumor was well differentiated, so that the long-term prognosis is reasonably good.

MR imaging provides greater anatomic detail and better tissue characterization of gangliogliomas than does CT. Spinal cord tumors usually have prolonged $\mathrm{T}_{1}$ and $\mathrm{T}_{2}$ relaxation times. Scotti et al. ${ }^{18)}$ noted that a tumor involving the entire cord and having a homogeneously prolonged $T_{2}$ relaxation time is most likely an astrocytoma; that a small nodule with a signal similar to that of normal parenchyma and associated with numerous cysts is most likely an ependymoma; and that a tumor with serpiginous, signal-void areas is most likely a hemangiomas. However, in some cases it is difficult to diagnose on the basis of MR images alone. Our patient's tumor displayed an area of isointensity surrounded by high intensity on $T_{1}$-weighted images, and high intensity on $T_{2}$-weighted images, which is not specifically diagnostic of either glial or vascular tumors. The MR images did, however, indicate the exact size and location of the tumor, and thus provided a significant guideline for treatment. MR imaging is also very helpful in the postoperative evaluation and management of patients with gangliogliomas.

\section{Acknowledgment}

The authors thank Associate Professor Brian T. Quinn, Medical Editor of Kyushu University, Fukuoka, for his assistance in the preparation of this manuscript.

\section{References}

1) Albright L, Byrd RP: Ganglioglioma of the entire spinal cord. Childs Brain 6: 274-280, 1980

2) Bevilacqua G, Sarnelli R: Ganglioglioma of the spinal cord. A case with a long survival. Acta Neuropathol (Berl) 48: 239-242, 1979

3) Courville CB: Ganglioglioma. Tumor of the central nervous system. Review of the literature and report of two cases. Arch Neurol Psychiat 24: 439-491, 1930

4) Courville CB, Anderson FM: Neuro-gliogenic tumors of central nervous system. Report of two additional cases of ganglioglioma of the brain. Bull Los Angeles Neurol Soc 6: 154-176, 1941 
5) Foerster A: Ein Ganglioneurom des Rückenmarks. Virchow Arch Path Anat 253: 116-124, 1924

6) Foerster $O$, Gagel O: Ein Fall von Gangliocytom der Oblongata. Zeitschrift für die gesamte Neurologie und Psychiatrie 141: 797-823, 1932

7) Garrido E, Becker LF, Hoffman HJ, Hendrick EB, Humphreys R: Gangliogliomas in children. A clinicopathological study. Childs Brain 4: 339-346, 1978

8) Kalyanaraman UP, Henderson JP: Intramedullary ganglioneuroma of spinal cord: A clinicopathologic study. Hum Pathol 13: 952-955, 1982

9) Kernohan JW, Learmonth JR, Doyle JB: Neuroblastomas and gangliocytomas of the central nervous system. Brain 55: 287-310, 1932

10) Kernohan JW, Woltman HW, Adson AW: Intramedullary tumors of the spinal cord. A review of fifty-one cases, with an attempt at histologic classification. Arch Neurol Psychiat 25: 679-699, 1931

11) Kitano $M$, Takayama $S$, Nagao $T$, Yoshimura $O$ : Malignant ganglioglioma of the spinal cord. Acta Pathol Jpn 37: 1009-1018, 1987

12) Koos W, Laubichler W, Sorgo G: Statistische Untersuchungen bei spinalen Tumoren im Kindes- und Jugendalter. Neuropaediatrie 4: 273-303, 1973

13) Lichtenstein BW, Zeitlin H: Ganglioglioneuroma of the spinal cord associated with pseudosyringomyelia. A histologic study. Neurol Psychiatr (Bucur) 37: 1356-1370, 1937

14) Perkins OC: Ganglioglioma. Arch Pathol Lab Med 2: $11-17,1926$
15) Pick L, Bielshowsky M: Über das System der Neurome und Beobachtungen an einem Ganglioneurom des Gehirns (nebst Untersuchungen über die Genese der Nervenfasern in "Neurinomen"). Zeitschrift für die gesamte Neurologie und Psychiatrie 6: 391-437, 1911

16) Russell DS, Rubinstein LJ: Ganglioglioma. A case with long history and malignant evolution. $J$ Neuropath Exp Neurol 21: 185-193, 1962

17) Russell DS, Rubinstein LJ: Tumors of the Central Nervous System, ed 4. London, Edward Arnold, 1977, pp 260-270

18) Scotti G, Scialfa G, Colombo N, Landoni L: Magnetic resonance diagnosis of intramedullary tumor of the spinal cord. Neuroradiology 29: 130135, 1987

19) Wald U, Levy PJ, Rappaport ZH, Michowitz SD, Schuger L, Shalit MN: Conus ganglioglioma in a 2 1/2-year-old boy. Case report. J Neurosurg 62: $142-144,1985$

20) Zimmerman $\mathrm{H}$ : Introduction to tumors of the central nervous system, in Mincker J (ed): Pathology of the Nervous System, vol 2. New York, McGraw-Hill, 1971, pp 1947-1951

Address reprint requests to: K. Kamikaseda, M.D., Department of Neurosurgery, Kaizuka Hospital, 7-7-27 Hakozaki, Higashi-ku, Fukuoka 812, Japan. 